\title{
Expression and Evaluation of Immuno-Reactivity of Recombinant VP2 Protein of Bluetongue Virus Serotype-23
}

\author{
Priya Sharma, Karam Chand*, Sanchay Kumar Biswas, M. Sankar, Arpit Saxena, \\ Sujoy Tamang, Ankita Lohumi and Muthannan Andavar Ramakrishnan
}

Division of Virology, ICAR-Indian Veterinary Research Institute, Mukteswar Campus, Dist. Nainital 263 138, Uttarakhand, India

*Corresponding author

\section{A B S T R A C T}

\begin{tabular}{|l|}
\hline Ke y w o r d s \\
Bluetongue virus, \\
BTV-23, Recombinant \\
VP2 protein, Immuno- \\
reactivity \\
\hline Article Info \\
\hline $\begin{array}{l}\text { Accepted: } \\
\text { 10 July } 2018 \\
\text { Available Online: } \\
\text { 10 August } 2018\end{array}$ \\
\hline
\end{tabular}

\section{Introduction}

Bluetongue virus (BTV), the causative agent of bluetongue (BT) is an arthropod-borne disease of domestic and wild ruminants (Mertens et al., 2005). The disease is transmitted between domestic and wild ruminants by Culicoides species which are most abundant and active in hot and humid climate (Mellor, 1990). At present, worldwide 27 distinct BTV serotypes have been identified (Zientara et al., 2014). The BTV genome consists of ten segmented doublestranded RNA (dsRNA) which code for seven structural (VP1- VP7) and four non-structural
(NS1, NS2, NS3/NS3A and NS4) proteins (Belhouchet et al., 2011). BTV is enzootic in India and 26 serotypes of the virus have been reported based on serology and virus isolation. So far, at least 13 different serotypes (BTV-1$4,6,9,10,12$ 16-18, 21 and 23) of BTV were isolated from the country (Chand et al., 2015).

The diagnosis of BT requires isolation of virus, standard serological methods and other nucleic acid and antigen detection assays (Afshar, 1994; Clavijo et al., 2000). Competitive ELISA (c-ELISA), indirect ELISA (i-ELISA) and agar gel immunodiffusion (AGID) assay can be used 
for the detection of serogroup-specific antibodies (Afshar et al., 1989; Chand et al., 2017). Molecular tools such as reversetranscriptase polymerase chain reaction (RTPCR), Real-time PCR and Loop-Mediated Isothermal Amplification (LAMP) have also been demonstrated for detection of viral nucleic acid in the clinical samples (Shaw et al., 2007; Mohandas et al., 2015). Due to the presence of a large number of susceptible hosts, BTV serotypes and Culicoides vector, the control of BT is difficult. Vaccination is the most effective control strategy for developing countries like India. Rapid and reliable identification of virus serotype can, therefore, play an important part in the design and implementation of appropriate control measures. Identification of BTV 'type' also demonstrates conclusively that the virus belongs to the BTV species, confirming any initial diagnoses by other means, and can help to map the origins, movement and spread of individual virus strains (Hamblin et al., 2004). In India, an inactivated pentavalent vaccine containing most prevalent serotypes (BTV-1, 2, 10, 16 and 23) was developed and commercialized (Reddy et al., 2010). Detection of serotypes is necessary for taking up effective control measures including vaccination. VP2 is the most variable nonglycosylated BTV proteins and is a major protective antigen. The specificity of its interactions with neutralizing antibodies determines the identity of the known BTV serotypes (Maan et al., 2011). BTV serotypes can be identified by virus neutralization test (VNT), RT-PCR followed by sequencing of VP2 gene and type-specific real-time RT-PCR (Breard et al., 2016; Maan et al., 2016). These entire assays are tedious, time taking and only small number of samples can be tested at a time. Serological typing methods like VNT require access to standardized reagents, including reference antiserum, or reference strains for all 26 BTV serotypes, which can be difficult to produce and could be a potential infection risk (Maan et al., 2012). In addition, for VNT, live and characterized BTV serotype strains are needed and it must be performed in a BSL3 laboratory (Breard et al., 2016). Therefore alternative assay like serotypespecific ELISAs will be a good choice for detection of BTV antigen and antibody. A serotype-specific ELISA will be much faster, economical and easier to perform compared to VNT or other nucleic acid-based assays. Moreover, a large number of clinical or laboratory samples could be screened in a less time in epidemiological studies and also the assay can be completed within 4-5 hr. Therefore, in present study VP2 protein of BTV-23 serotype (prevalent serotype in India) was expressed in prokaryotic system and assessed for its potential use as a candidate for the development of serotype-specific BTV diagnostic assay.

\section{Materials and Methods}

\section{Cloning of the VP2 protein of BTV-23 in transfer vector}

The total RNA of BTV-23 serotype (Parbhani/Ind) was extracted by Tri-Reagent (Sigma, St. Louis, USA). BTV dsRNA was purified by sequential precipitation by lithium chloride ( $\mathrm{LiCl})$. RT-PCR of purified viral dsRNA was carried out using VP2 genespecific primers. The forward and reverse primers with BamHI restriction enzyme (RE) recognition site [BTV23/S2/F: 5'CGCGGATCCTGGTTACAGTGGATGATCG3') and XhoI RE site (BTV23/S2/R: 5'GTGCTCGAGGTCATGAGCGTATAGTAGG-

3') respectively were designed using published sequences. The amplification was carried out using GoTaq ${ }^{\circledR}$ Long PCR Master Mix (Promega, Madison, USA) and the cycling conditions followed were: initial denaturation at $94{ }^{\circ} \mathrm{C}$ for $5 \mathrm{~min}$, denaturation at $95{ }^{\circ} \mathrm{C}$ for $30 \mathrm{sec}$, annealing at $59{ }^{\circ} \mathrm{C}$ for 30 sec and extension at $68{ }^{\circ} \mathrm{C}$ for $2 \mathrm{~min}$ for 35 
cycles with a final extension of $68{ }^{\circ} \mathrm{C}$ for 10 min. The PCR amplicon was gel purified and cloned directionally into pET32a vector (Novagen, Madison, WI, USA) with BamHI and XhoI restriction sites. The recombinant clones were selected on LB agar plates containing ampicillin $(50 \mu \mathrm{g} / \mathrm{ml})$ and were verified by restriction enzyme analysis, and sequencing.

\section{Expression and purification of recombinant VP2 protein}

E. coli BL21 - CodonPlus (DE3) - RIPL cells were transformed with recombinant plasmid and grown at $37{ }^{\circ} \mathrm{C}$ overnight, on LB agar plates containing chloramphenicol $(34 \mu \mathrm{g} / \mathrm{ml})$ and amplicillin $(50 \mu \mathrm{g} / \mathrm{ml})$. E. coli BL21 CodonPlus (DE3) - RIPL with pET32a-VP2 were grown in LB medium supplemented with antibiotics at $37^{\circ} \mathrm{C}$ to an optical density at 600 $\mathrm{nm}$ of approximately 0.6 . Protein expression was induced by adding IPTG to $1 \mathrm{mM}$ final concentration. Then, additional $5 \mathrm{~h}$ incubation at $37{ }^{\circ} \mathrm{C}$ with vigorous shaking at $180 \mathrm{rpm}$. After the cells were harvested by centrifugation at $5000 \times \mathrm{g}$ for $10 \mathrm{~min}$ at $4{ }^{\circ} \mathrm{C}$, cell lysate was sonicated, centrifuged and purified using nickel affinity columns according to the manufacturer's instructions with some modification (M/s Qiagen, Hilden, Germany). Briefly, after centrifugation the supernatant was discarded while the pellet was resuspended in Tris- $\mathrm{HCl}(50 \mathrm{mM} ; \mathrm{pH}$ 7.6). The cells were disrupted by lysozyme, freezethawing and ultrasonication for $10 \mathrm{~min}$ with $20 \mathrm{sec}$ intervals between pulses. The cell lysate was then centrifuged at $18000 \mathrm{rpm}$ at 4 ${ }^{\circ} \mathrm{C}$ for $20 \mathrm{~min}$. The pellet was resuspended with denaturing binding buffer $(0.01 \mathrm{M}$ Na2HPO4, 0.01 M NaH2PO4, 0.5 M NaCl, 8 $\mathrm{M}$ urea, $\mathrm{pH}$ 8.0). The denatured pellet was centrifuged at $18000 \mathrm{rpm}$ for $20 \mathrm{~min}$ at $4{ }^{\circ} \mathrm{C}$. Supernatant was filtered using $0.45 \mu \mathrm{m}$ membrane filters and transferred to a fresh tube. To the Ni-NTA agarose superflow column pre-equilibrated with the binding buffer, supernatant was passed slowly $(1 \mathrm{ml} /$ minute) and column was sequentially washed with the wash buffer $\left(0.01 \mathrm{M} \mathrm{Na}_{2} \mathrm{HPO}_{4}, 0.01\right.$ $\mathrm{M} \mathrm{NaH} 2 \mathrm{PO}_{4}, 0.5 \mathrm{M} \mathrm{NaCl}, 6 \mathrm{M}$ urea, pH 6.5). Then recombinant protein was eluted using elution buffer $\left(0.01 \quad \mathrm{M} \mathrm{Na}_{2} \mathrm{HPO}_{4}, 0.01 \mathrm{M}\right.$ $\mathrm{NaH}_{2} \mathrm{PO}_{4}, 0.5 \mathrm{M} \mathrm{NaCl}, 4 \mathrm{M}$ urea, $\mathrm{pH} 4.0$ ) and dialyzed. The final concentration of purified protein was estimated colorimetrically using Micro BCA Protein Assay Kit (Pierce, Rockford, IL, USA). The harvested postinduced samples at 2-5 h, uninduced samples, and eluted fractions were mixed separately with SDS Laemmli sample buffer and analysed by polyacrylamide gel $(5 \%$ stacking and $10 \%$ resolving). The resolved protein was transferred on to a nitrocellulose membrane (M/s Pharmacia Biotech, USA using semi-dry blot system (M/s ATTO corporation, Japan). The recombinant protein on the blot was detected by incubation with Ni-NTA HRP conjugate (1:2000 dilution) as per the standard procedure.

\section{Imuno-reactivity of BTV23- rVP2 with HIS}

The immuno-reactivity of the recombinant BTV-23 rVP2 protein was determined using BTV-23 HIS raised in rabbit in Indirect ELISA. The cross-reactivity of rVP2 BTV-23 with HIS against BTV-1 was also evaluated. Breifly, the recombinant VP2 antigen in 100$1000 \mathrm{ng}$ conc. were diluted in carbonatebicarbonate buffer and $50 \mu \mathrm{l}$ of each dilution was coated in duplicates in a 96 well plate and incubated for $1 \mathrm{~h}$ at $37{ }^{\circ} \mathrm{C}$. Then unbound areas on the plate were blocked with $1 \% \mathrm{BSA}+1 \% \mathrm{SMP}$ and the plate was washed three times with washing buffer (PBST). Then two fold dilutions of HIS (against BTV-23 and BTV-1) and negative serum were added. After incubation and washing, anti-Rabbit HRPO conjugate (Sigma-Aldrich, St. Louis, USA) was added for $1 \mathrm{~h}$ at $37{ }^{\circ} \mathrm{C}$. After washing, substrate $\left(\mathrm{OPD}+\mathrm{H}_{2} \mathrm{O}_{2}\right.$ ) solution was added to 
all the wells and incubated in dark for 15 minutes. The reaction was stopped using $1 \mathrm{M}$ $\mathrm{H}_{2} \mathrm{SO}_{4}$. The optical density (OD490 value) was measured at $492 \mathrm{~nm}$ using a Microplate Reader (Bio-Rad, USA).

\section{Results and Discussion}

For amplification of segment-2 gene, BTV (23)-VP2 (aa662) at N-terminal of VP2 protein was targeted. The amplified product with serotype-specific primers was visualized by resolving in $1 \%$ agarose gel and the sizes of the amplified product was $1986 \mathrm{bp}$. Both gel purified PCR product and vector DNA were double digested with BamHI and XhoI for directional cloning.

The fragments at their appropriate ratios were ligated with digested linearized vector using $\mathrm{T}_{4}$ DNA ligase. The E. coli TOP 10F' competent cells were transformed with the ligated mixture and transformants were screened on LB agar plates containing ampicillin. The plasmids subjected to double digestion with BamHI and XhoI showed the insert release of the recombinant plasmid in agarose gel. The identity of sequence data thus generated was confirmed by nucleotide BLAST (NCBI) analysis. BLAST (NCBI) analysis confirmed that serotype (BTV- 23) was having sequence homology with published sequences of BTV-23 serotype available in the database (GenBank: BTV-23/ AY643506).

The positive clone was transformed into bacterial expression host so as to over-express the target protein. During expression studies, the optimum level of expression of VP2 protein was seen at $37{ }^{\circ} \mathrm{C}$ after $5 \mathrm{~h}$ of induction with $1 \mathrm{mM}$ IPTG. The expression study revealed that the expressed protein was insoluble and found in the insoluble fraction of cell lysate. The protein expressed was analyzed in SDS-PAGE and protein of expected size ( $90 \mathrm{kDa})$ was observed in the induced positive clone (Fig. 1). The recombinant VP2 protein, in the insoluble fraction of the bacterial cell lysate was purified under denaturing condition. Confirmation of the expressed protein was done by Western blot analysis using Penta-his HRP conjugate. The purity of protein analysed in SDS-PAGE and Western blotting revealed homogenous purity of the protein with the appearance of respective protein size product ( 90 kDa) (Fig. 2a and b). The immunoreactivity and cross-reactivity of $\mathrm{rVP} 2$ protein was assessed with homologous and heterologous HIS against BTV-23 and BTV-1 respectively. An indirect ELISA format was used to test the diagnostic potential of the expressed rVP2 protein. In order to find out the single sera dilution and antigen concentration, a chequer board titration was done. The optimum antigen concentrations for rVP2 BTV-23 was found to be $250 \mathrm{ng} / \mathrm{well}$ at BTV-23 HIS dilution of 1:50. At this concentration, the OD490 value of BTV-23 HIS, BTV-1 HIS and negative serum were 1.1, 0.32 and 0.4 respectively. There was no crossreactivity of rVP2 BTV-23 with HIS against BTV-1 (Fig. 3).

In present study, truncated VP2 protein of BTV serotype 23 was expressed in prokaryotic system and its potential use as a candidate for the development of serotype-specific BTV diagnostics assay was assessed. Bacterial system was used for the production of recombinant antigen, as large quantities of viral antigen with good purity can be obtained. One of the main advantages of bacterial expression is the low cost associated, with rapid and high productivity of heterologous proteins (Georgiou and Valax, 1996). It might also be necessary to mention that the lack of a post-translational modification pathway in the prokaryotic expression system should not be of a disadvantage since BTV-VP2 is a nonglycosylated protein (Roy, 2008). 
Fig.1 SDS-PAGE analysis of BTV-23 VP2 protein expressed at $37^{\circ} \mathrm{C}$ with $1 \mathrm{mM}$ IPTG at 5 hour post induction. Lanes; (1): pET-32a/BL21 without induction; (2): Recombinant BTV-23 VP2 protein expressed in E. Coli BL21 [insoluble fraction]; (3): Soluble fraction

(M): Protein Marker (puregene)

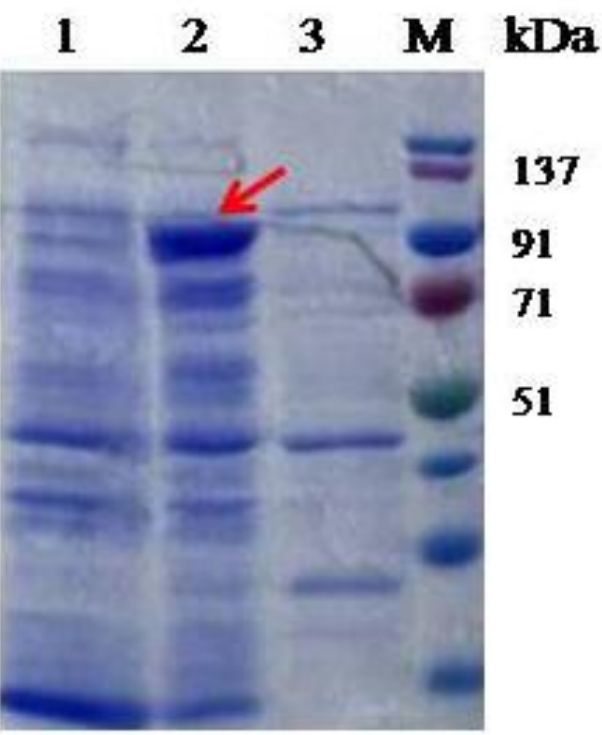

Fig.2 a] Western blot assay using Ni-NTA HRP conjugate at 1:2000 dilution for the detection of protein expression. Lanes; (M): Protein marker (Puregene) (1) Induced recombinant BL21 CodonPlus (DE3) expressing BTV (23)-VP2 protein; b] Purified fractions of BTV (23)-VP2 in 10\% SDS-PAGE. Lanes; (M): Protein marker (Puregene). (1) Purified fraction of recombinant $\mathrm{BTV}(23)-\mathrm{VP} 2$ protein

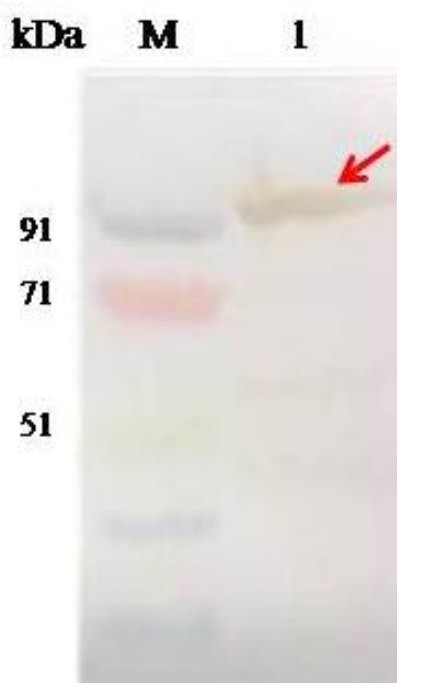

a)

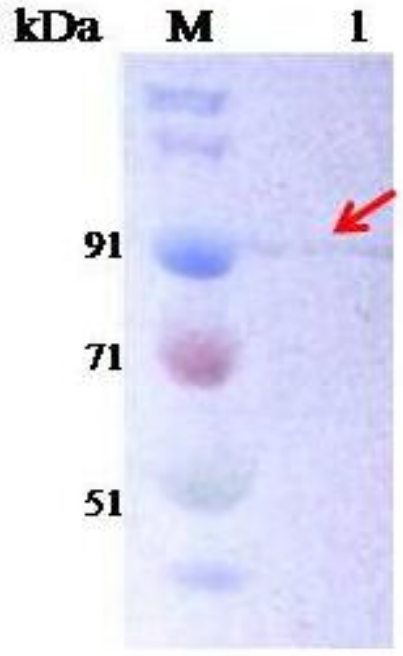

b) 
Fig.3 Determination of optimum conc. /dilution of r VP2 BTV-23 protein and HIS (BTV-23) by chequer board titration method and detection of cross reactivity of $r$ vP2 BTV-23 protein with HIS of BTV-1. The optimum antigen concentrations for rVP2 BTV-23 was found to be 250 ng/well at BTV-23 HIS dilution of 1: 50

Serumdifinim $=1-50$

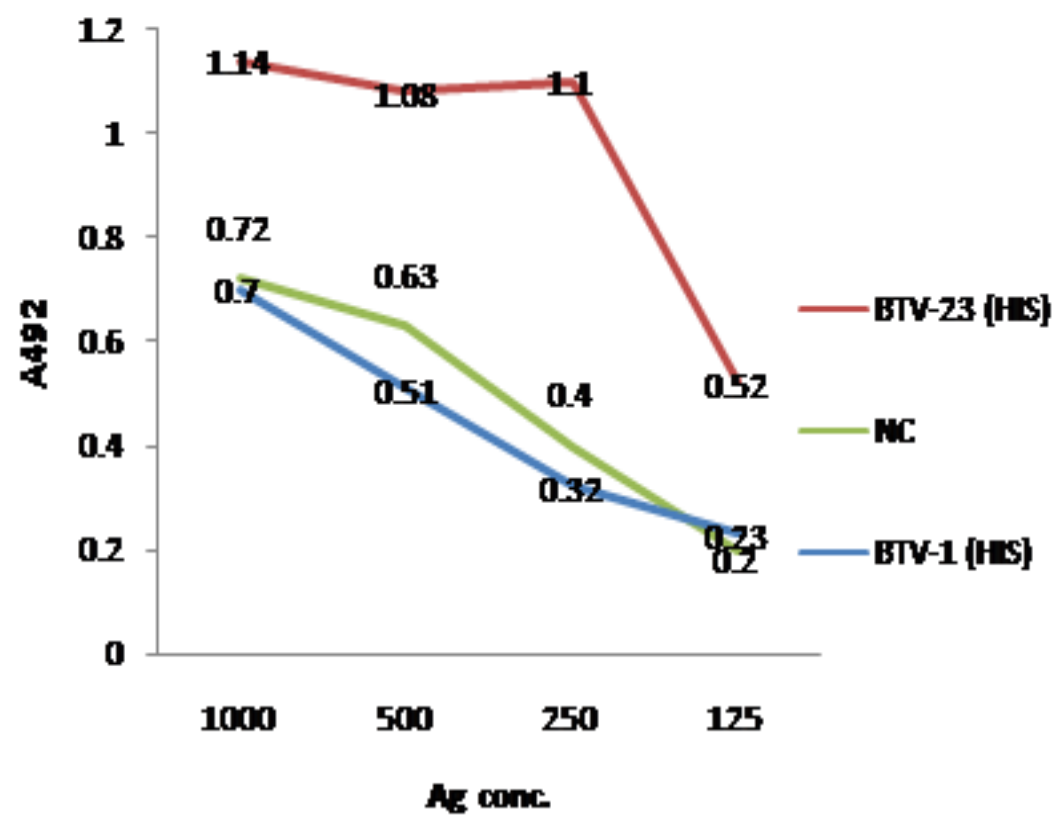

The VP2 protein was targeted as truncated fragment ( $\mathrm{N}$-terminal) as the expression of full length VP2 proved difficult, probably because expression of recombinant proteins over larger residues is problematic in prokaryotic system, since these proteins are often unstable or form insoluble inclusion bodies (Sambrook and Russell, 2001). The expression of VP2 protein was carried out in E.coli BL21 CodonPlus (DE3) cells using the pET32a expression vector, as protein with high purity and solubility can easily be obtained by affinity chromatography due to the two histidine tags on both sides of the protein. During expression studies the optimum level of expression of VP2 proteins were seen at $37{ }^{\circ} \mathrm{C}$ after $5 \mathrm{~h}$ of induction with $1 \mathrm{mM}$ IPTG. The expression study revealed that, all of the expressed proteins were insoluble since they could only be found in the insoluble fraction. This is in agreement with a previous study by Han et al., (2017), where truncated $\mathrm{rVP} 2$ proteins were purified from the insoluble fraction. In the bacterial system, the presence of the recombinant proteins in the insoluble fraction is a common occurrence during cytoplasmic over-expression in prokaryotic expression systems. An indirect ELISA format was used to test the diagnostic potential of the proteins. Though other immunoassays can be applied, ELISA is one of the most sensitive methods to evaluate expressed proteins and has been extensively applied in the diagnosis of BTV (Inumaru et al., 1987; Pathak et al., 2008; Barros et al., 2009). To evaluate the immuno-reactivity and cross-reactivity of rVP2, homologous and heterologous HIS against BTV-23 and BTV-1 respectively were used. The rVP2 protein gave good immunoreactivity with homologous HIS and there was no cross reactivity with heterologous HIS. The generated rVP2 protein will be promising candidate for the development of a serological 
diagnostic test for detection of serotype-specific antibody against BTV-23.

In conclusion, the present study has successfully produced a recombinant VP2 protein of BTV-23 and immuno-reactivity and cross-reactivity were evaluated homologous and heterologous HIS against BTV-23 and BTV-1 respectively. The expressed $\mathrm{rVP} 2$ protein will be potential candidate for the development of serotype specific diagnostic assay for detection of type specific antibody against BTV-23. Further, the cross- reactivity of the rVP2 protein to all serotype-specific anti-BTV sera is needed to be evaluated.

\section{Acknowledgement}

This work has been supported by an ICAR (No.F.13 (1)/2000-ASRIV) project- All India Network Programme on Bluetongue. The authors wish to thank the Director ICAR-IVRI; Head, Division of Virology and the Coordinator, AINP-BT project for providing the facilities.

\section{Conflict of Interest}

The authors declare no conflict of interest

\section{References}

Afshar, A. 1994. Bluetongue: laboratory diagnosis. Comp. Immune. Microbial. Infect. Dis. 17: 221 -242.

Afshar, A., Thomas, F. C., Wright, P. F., Shapiro, J. L. and Anderson J. 1989. Comparison of competitive ELISA, indirect ELISA and standard AGID tests for detecting bluetongue virus antibodies in cattle and sheep. Vet. Rec. 124:136141.

Barros, S. C., Cruz, B., Luı's, T. M., Ramos, F., Fagulha, T., Margarida Duarte, M., Henriques, M. and Fevereiro, M. 2009. A DIVA system based on the detection of antibodies to non-structural protein 3 (NS3) of bluetongue virus. Vet. Microbiol. 137: 252-259.
Belhouchet, M., Jaafar, M. F., Andrew, E., Grimes, M. J., Mertens, P. P. C. and Attoui, H. 2011. Detection of a fourth orbivirus non-structural protein. PloS One 6: e25697.

Breard, E., Garnier, A., Després, P., Blaise Boisseau, S., Comtet, L., Viarouge, C., Bakkali- Kassimi, L., Pourquier, P., Hudelet, P., Vitour, D. and Rossi, S. 2016. Development of a double- antigen microsphere immunoassay for simultaneous group and serotype detection of bluetongue virus antibodies. Transbound. Emerg. Dis. doi:10.1111/tbed.12578.

Chand, K., Biswas, S. K., Pandey, A. B., Saxena, A., Tewari, N. and Mondal, B. 2017. A competitive ELISA for detection of group specific antibody to bluetongue virus using anti-core antibody. Biologicals 46: 168-171.

Chand, K., Biswas. S. K., Pandey, A. B., Muthuchelvan, D., Mondal, B. 2015. Bluetongue in India: A review. Adv Anim Vet Sci 3: 605-612.

Clavijo, A., Heckert, R. A., Dulac, G. C. and Afshar, A. 2000. Isolation and identification of bluetongue virus. $\mathrm{J}$. Virol. Methods 87(1-2): 3-23.

Georgiou, G. and Valax, P. 1996. Expression of correctly folded proteins in Escherichia coli. Curr Opin Biotechnol. 7(2): 190197.

Hamblin, C. 2004. Bluetongue virus antigen and antibody detection, and the application of laboratory diagnostic techniques. Vet. Ital. 40: 538-545.

Han, Z., Mingxin, Z., Xuechun, L., Yigang, X., Xinyuan, Q., Li, W., Wen, C., Yanping, J., Yijing, L. and Lijie, T. 2018. Development of Competitive EnzymeLinked Immunosorbent Assays for Antibody Detection Based on Bluetongue Virus Monoclonal Antibodies. Viral Immunol. 31(3): 264-271.

Inumaru, S., Ghiasi, H. and Roy, P. 1987. Expression of bluetongue virus groupspecific antigen VP3 in insect cells by a baculovirus vector: its use for the 
detection of bluetongue virus antibodies. J. Gen. Virol. 68: 1627-1635.

Maan, N., Maan, S., Nomikou, K., Prasad, G., Singh, K. P., Belaganahalli, M. N. and Mertens, P. P. 2012. Full genome sequence of bluetongue virus serotype 1 from India. J Virol. 86: 4717-4718.

Maan, S., Maan, N. S., Nomikou, K., Veronesi, E., Bachanek-Bankowska, K., Belaganahalli, M. N., Attoui, H. and Mertens, P. P. 2011. Complete genome characterisation of a novel 26th bluetongue virus serotype from Kuwait. PLoS One 6: e26147.

Maan, Sushila, Narender Singh Maan, Manjunatha N. Belaganahalli, Abraham C. Potgieter, Vinay Kumar, Kanisht Batra, Isabel M. Wright, Peter D. Kirkland, and Peter PC Mertens. 2016. Development and evaluation of real time RT-PCR assays for detection and typing of Bluetongue virus. PloS one11, no. 9: e0163014.

Mertens, P. P. C., Maan, S., Samuel, A. and Attoui, H. 2005. Orbivirus, Reoviridae. In: C.M. Fauquet, M. A. Mayo, J. Maniloff, U. Desselberegr and L. A. Ball. eds. Virus Taxonomy, VIII Report of the ICTV. London, Elsevier-Academic Press, pp. 466-483.

Mohandas, S. S., Muthuchelvan, D., Pandey, A. B., Biswas, S. K., Chand, K., Venkatesan, G., Choudhary, D., Ramakrishnan, M. A. and Mondal, B. 2015. Development of reverse transcription loop mediated isothermal amplification assay for rapid detection of bluetongue viruses. J. Virol. Methods 222: 103-105.

Pathak, K. B., Biswas, S. K., Tembhurne, P. A., Hosamani, M., Bhanuprakash, V., Prasad,
G., Singh, R. K., Rasool, T. J. and Mondal B. 2008. Prokaryotic expression of truncated VP7 of Bluetongue virus (BTV) and reactivity of the purified recombinant protein with all BTV typespecific sera. J. Virol. Meth. 152: 6-12.

Reddy, Y. K. M., Manohar, B. M., Pandey, A. B., Reddy, Y. N., Prasad, G. and Chauhan, R. S. 2010. Development and evaluation of inactivated pentavalent adjuvanted vaccine for Bluetongue. Indian Vet. J. 87: 434-436.

Roy, P. 2008. Functional mapping of bluetongue virus proteins and their interactions with host ruminants. Comp. Immunol. Microbiol. Infect. Dis. 17: 197217.

Sambrook, J. and Russell, D. W. 2001. Molecular Cloning: A laboratory manual. Volume 1 and 3. $3^{\text {rd }}$ ed. New York, Cold Spring Harbor Laboratory Press. pp. $1.119,15.14$.

Shaw, A. E., Monaghan, P., Alpar, H. O., Anthony, S., Darpel, K. E., Batten, C. A., Guercio, A., Alimena, G., Vitale, M., Bankowska, K. and Carpenter, S. 2007. Development and initial evaluation of a real-time RT-PCR assay to detect bluetongue virus genome segment 1 . J. Virol. Methods 145(2): 115-26.

Zientara, S., Sailleau, C., Viarouge, C., Höper, D., Beer, M., Jenckel, M., Hoffmann, B., Romey A., Bakkali-Kassimi, L., Fablet, A., Vitour, D. and Bréard, E. 2014. Novel bluetongue virus in goats, Corsica, France. Emerg Infect Dis 20: 2123-2125.

\section{How to cite this article:}

Priya Sharma, Karam Chand, Sanchay Kumar Biswas, M. Sankar, Arpit Saxena, Sujoy Tamang, Ankita Lohumi and Muthannan Andavar Ramakrishnan. 2018. Expression and Evaluation of Immuno-Reactivity of Recombinant VP2 Protein of Bluetongue Virus Serotype-23. Int.J.Curr.Microbiol.App.Sci. 7(08): 1540-1547. doi: https://doi.org/10.20546/ijcmas.2018.708.176 